\title{
Use of miRNA as a Biomarker in Prostate Cancer and New Approaches
}

\author{
(D) Elif Sibel ASLAN, ${ }^{1}$ (D) Sefa ÇETINKAYA ${ }^{2}$ \\ 'Department of Molecular Biology and Genetics, Biruni University, İstanbul-Turkey \\ ${ }^{2}$ Department of Molecular Biology and Genetics, Biruni University, İstanbul-Turkey
}

\begin{abstract}
SUMMARY
Prostate cancer has been found to be the most life-threatening disease among men all over the world, given its wide occurrence and partially-successful therapies associated with a high rate of mortality. Thus, meticulous analysis of this cancer and its characteristics, including molecular biology, epigenetic mechanisms and markers during tumor development, may provide the scientists with valuable insights to design the therapeutic protocol with improved efficiency and low rate of failure and limited further side effects, such as infertility. Moreover, the risk associated with the current invasive procedures on prostate cancer patients has prompted researchers to invest effort in the discovery of being less-invasive and more advantageous procedures based on the patient's own physiological and anatomical characteristics. This paper reviews past and present studies on epigenetics and molecular markers of prostate cancer, as well as the designed therapies. Additionally, we present a future vision and prospect of the current treatments.
\end{abstract}

Keywords: CRISPR-Cas; epigenetic mechanisms; miRNA; prostate cancer.

Copyright $\odot$ 2020, Turkish Society for Radiation Oncology

\section{Introduction}

Prostate cancer (PC), unlike many other cancers, such as lung cancer, has been posing a huge threat to men due to lack of its connection with carcinogenic chemicals and heterogeneity of prostate glands which has made it rather difficult to analyze the sole cause of cancer and eventually efficient precaution that arises from constraint causative factors.[1] PC has been in existence since ancient times; hence, the development of prostatectomy, a surgical means for PC treatment, has been achieved for more than a century.[2] PC is described as a heterogeneous type of cancer that exhibits various forms, from the slow-growing tumors to fast-growing tumors, which gradually turns out to be fatal. Years of studies and analysis have provided a rather more convenient way for the diagnosis of PC. Prostate-specific antigen (PSA) blood test is performed to determine the presence of kallikrein-related serine protease, the enzyme which is normally found in prostate secretion, but found in the bloodstream due to functional and histological anomaly of the prostate, and helps to diagnose PC in early stages for further treatment.[3]

Human serine proteases are members of human tissue kallikrein (KLK) family, which contain 15 homologues serine proteases (KLK1-KLK15). This family is encoded by the largest clustered human genome located on chromosome 19 [4], out of which KLK2 and KLK3 are found only in prostate and KLK3 with $33-\mathrm{kDa}$ weight are considered as the biomarker (PSA) in PC screening. [4,5] Discovery of PSA dates back to 1979 when it was found in prostatic tissues.[6] Apart 
from contributing to cancer diagnosis, KLK3 is the main modulator of sperm status in terms of semen liquefaction and coagulation.[7] Genetic polymorphism of KLK3 has also been shown to contribute to the high risk of male infertility as a degrading factor to semenogelin. [8] However, KLK3 activation and defragmentation are controlled by the KLK14 function, which was detected by analysis of KLK3 fragments invitro using recombinant KLK14.[9]

The cancer is initiated and developed in the prostate gland, part of the male reproductive system responsible for semen production in the male body and located inferior to the bladder.[10] Approximately $98 \%$ of the PCs are reported to be of glandular origin.[11] This organ is made of epithelial cell clusters arranged in the form of the basal layer and contains stem cells, transit-amplifying cells (TACs), and committed basal (CB) cells as the most dominant cell population in this structure.[12] Based on histological analysis of prostate organ, stem cells undergo division to form TA cells, which further divide by mitosis and differentiate into $\mathrm{CB}$ cells, the only cell type in prostate capable of DNA synthesis and proliferation, which are finally transformed into differentiating luminal cells in human.[13] PC was observed with a lack of or disruptive basal layer along with the disruption of the above-mentioned cell number present in the prostate gland.[9] Such an irregular growth of stem cells was first noticed in 1989.[13]

Stem cells characterization, collected by biopsy of patients, were carried out using $\mathrm{CD} 44^{+} \alpha_{2} \beta 1$ hi CD $133^{+}$ markers as the phenotype, which unfortunately was not specific for only cancer stem cells (CSCs). [14] Additionally, PAP (prostatic acid phosphate) was found to not be fully special PC diagnosis since PAP was found to be elevated in benign prostatic hyperplasia $(\mathrm{BPH})$ and other organ's malfunctions, such as the liver.[15]

This paper reviews past and present studies on epigenetics and molecular markers of PC, as well as the designed therapies. Additionally, we present a future vision and prospect of the current treatments.

\section{miRNA and DNA Methylation in PC}

Studies on cancer show that epigenetic mechanisms are effective above cancer prognosis. miRNAs have been demonstrated that play a role in epigenetic mechanisms, such as DNA methylation and histone deacetylation (HDAC). [16,17]

There are regions called CpG islands, which are located there high rate repetition cytosine and guanine base pairs in the human genome. CpG islands mostly take part in promotor regions of a gene. In these re- gions, methylation occurs when attaching methyl (-CH3) to cytosine's fifth carbon. Abnormal situations, such as hypomethylation and hypermethylation, cause fall into decay cell functions, such as cell differentiation, cell division, and cell proliferation. $[18,19]$

Recent studies related to miRNA show that miRNA genes are situated near to $\mathrm{CpG}$ islands. In conclusion, methylation of the CpG islands will affect the expression of miRNAs. [20-22]

We can denote miRNA-152 as a sample to relationship miRNA and DNA methylation. In normal conditions, miRNA-152 prevent the expression of DNA (cytosine-5)-methyltransferase 1 (DNTM1) by targeting 3' UTR region of the DNMT1 gene. When DNMT1 expression and DNA methylation are lower, the gene is an expression. Studies with cell lines of PC show that methylation depending on increase DNMT1 expression down-regulate miRNA-152. Thus, the gene expression that serves a function in cell differentiation, cell division, and cell proliferation is prevented.[23,24]

\section{miRNA and Histone Deacetylation in PC}

miRNA and HDAC relationship is affecting the regulatory roles of epigenetic mechanism.[25] Change of electrostatic force in histone tails affects their binding to DNA. To illustrate the positive charge of lysine, amino acid in the amino tail is neutralized with acetylation of histone protein. Consequently, region binding to DNA of the histone protein is free, and the region is clarified to transcription factors, which causes expression in the region.[26] Two enzyme family function in here. One of them is acetyltransferase (HAT). The other is a histone deacetylase (HDAC). While HAT enzymes are acetylating the region, HDAC enzymes deacetylate the same region. This reversible situation identifies whether it will be an expression of the region. The breakdown of equilibrium between two enzymes brings about the malignity of the cell.[27] Table 1 shows HDAC classification.[28]

We can denote miRNA-449a as a sample to relationship miRNA and HDAC. In normal conditions, when expression miRNA-449, its down-regulate HDAC1, which brings on activation of p27/kipl transcription, which causes cell proliferation. Studies with cell lines of PC show that down-regulation of miRNA-449a cause to up-regulation of HDAC1. Because of the HDCA1, up-regulation activation of p27/kip1 transcription causes cell proliferation out of control.[29]

\section{Genetic Propensity and Markers of PC}

Various genome-wide association studies (GWASs) implicate single-nucleotide polymorphism (SNP) 
Table 1 HDAC classification [28]

\begin{tabular}{lllcc}
\hline Group & Class & Name & Cellular localization & Localization in body \\
\hline Classic (Zinc-dependent) & Class I & HDAC1 & Nucleus & Everywhere \\
& & HDAC2 & & \\
& & HDAC3 & & \\
& HDAC8 & Nucleus/Cytoplasma & Tissue-spesific \\
& Class II & HDAC4 & & \\
& & HDAC5 & & \\
& & HDAC7 & & Tissue-spesific \\
& HDAC9 & Cydoplasma & Tissue-spesific \\
& HDAC10 & & \\
NAD-dependent & HDAC11 & Nucleus/Cytoplasma & Nucleus/Cytoplasma & \\
\hline
\end{tabular}

NAD: Nicotinamide adenine dinucleotide; SIRT: Sirtuin

Table 2 Single nucleotide polymorphism region with PC [31]

\begin{tabular}{lcc} 
Chromosomal region & $\begin{array}{c}\text { Alternative } \\
\text { alleles }\end{array}$ & $\begin{array}{c}\text { Associated } \\
\text { allele }\end{array}$ \\
\hline $17 q 12$ & T, C & T \\
$17 q 12$ & G, A & G \\
$17 q 12$ & A, C & C \\
$17 q 24.3$ & G, T & G \\
$17 q 24.3$ & C, T & T \\
$17 q 24.3$ & A, G & A \\
$17 q 24.3$ & A, G & A \\
8q24 (region 1) & C, A & A \\
8q24 (region 1) & G, A & A \\
8q24 (region 1) & A, C & C \\
8q24 (region 1) & C, T & T \\
8q24 (region 1) & G, T & T \\
8q24 (region 2) & A, C & C \\
8q24 (region 2) & C, A & A \\
8q24 (region 3) & G, T & G \\
8q24 (region 3) & C, T & T \\
\hline
\end{tabular}

to be responsible for PC initiation.[30,31] (Table 2). Although previous studies showed specific mutations on chromosome 15 and 19 to be responsible for aggressive PC [32,33], another genome analysis study has reported some genes with a mutation in PC (Table $3)$. Unlike most of the cancer types, various analyses indicate no specific oncogene connected to PC [68] although some oncogene exhibit overexpression in some cancers observed during anti-androgen therapy. C-ERB-B2 oncogene, located on chromosome 17, appears to be elevated in hormone-refractory PC in response to anti-androgen therapy.[69] Moreover, EZH2
mRNA has shown a significant peak due to EZH2 protein encoded by EZH2 oncogene, which acts as a repressor of transcription and causes cell proliferation in PC.[70] Additionally, retinoblastoma (RB) proteins seem to be reduced in malignant $\mathrm{PC}$, which caused tumor cell proliferation.[71]

P53, also known as TP53, which protects against tumorgenesis, is observed to be increased in malignant and untreated PC, rather than primary or treated ones. [72] Some studies have tested wild type (WT) P53 with mutated P53 using DU145 cells (human prostate cancer cell lines) in response to chemotherapeutic drugs and observed that P53 increased tumor cells' susceptibility to drugs which could indicate high survival rate of prostatic cancer cells during chemotherapies when P53 is silenced or non-functional.[73] On the account of tumour suppressor genes being silenced resulting in PC cell's resistance, the other factor, over activation of androgen receptor (AR), plays significant role in development of castrate-resistant prostate cancer [74] due to hypermethylation of CpG islands (sequence of 5'-CG3') [75] on AR genes and proven to be not related to androgen level which was observed during anti-androgen therapy in PC patients. [76,77]

\section{miRNAs as Biomarkers in PC}

microRNAs, also known as miRNAs, are small, noncoding endogenous RNA molecules that are found in eukaryotes, as well as some viruses. They have been found to play a key role in RNA regulations and diagnosis of various diseases on account of their circulation in body fluids.[78] Recent studies on miRNA transcripts have demonstrated their significance as 
Table 3 Common genetic aberrations in PC

\begin{tabular}{|c|c|c|}
\hline Gene & Genomic alterations & Chromosomal region \\
\hline APC & Deletion & $5 q 22.2[33]$ \\
\hline AR & Amplification/mutations/splicing variants & $\mathrm{Xq12}[34,35]$ \\
\hline ATM & Deletion/mutation & $11 q 22.3[36,37]$ \\
\hline BRCA1 & Deletion/mutation & $17 q 21.31[38]$ \\
\hline BRCA2 & Deletion/mutation & $13 q 13.1[39]$ \\
\hline CHD1 & Deletion & $5 q 21.1[40,41,42]$ \\
\hline ERF & Deletion/mutation & $19 q 13.2[43,44]$ \\
\hline ERG & Fusion/deletion & $21 \mathrm{q} 22.2[45]$ \\
\hline ETS2 & Deletion & $21 \mathrm{q} 22.2[33]$ \\
\hline ETVs & Fusion/deletion & NA [46] \\
\hline $\mathrm{EZH} 2$ & Mutation & $14 q 21.1[47]$ \\
\hline FOXA1 & Mutation & $14 q 21.1[40,48]$ \\
\hline IDH1 & Mutation & $2 q 34[49]$ \\
\hline KMT2A (MLL1) & Mutation/deletion & $11 q 23.3[50]$ \\
\hline KMT2C (MLL3) & Mutation/deletion & $7 q 36.1[39]$ \\
\hline KMT2D (MLL2) & Mutation/deletion & $12 q 13.12[51]$ \\
\hline KDM1A (LSD1 [lysine-specific demetthylase 1]) & Mutation/deletion & $1 p 36.12[52]$ \\
\hline KDM3A (JMKD1A) & Mutation/deletion & $2 \mathrm{p} 11.2, \mathrm{Xp} 11.3[53]$ \\
\hline \multicolumn{3}{|l|}{ KDM6A (UTX) } \\
\hline MYCN & Amplification & $2 p 24.3[54,55,56]$ \\
\hline NCOR1 & Deletion/mutation & $17 p 11.2[57]$ \\
\hline NCOR2 & Deletion/mutation & $12 q 24.31[58]$ \\
\hline NKX3-1 & Deletion & $8 p 21.2[59,60]$ \\
\hline PTEN & Deletion/mutation & $10 q 23.31[33,40,61]$ \\
\hline RB1 & Deletion/mutation & $13 q 14.2[51,62]$ \\
\hline SMAD4 & Deletion/mutation & $18 q 21.2[63,64]$ \\
\hline SPOP & Mutation & $17 q 21.33[40,65,66]$ \\
\hline TP53 & Deletion/mutation & $17 p 13.1[40,51,67]$ \\
\hline
\end{tabular}

PC: Prostate cancer; APC: Adenomatous polyposis coli; AR: Androgen receptor; ATM: ATM serine/threonine kinase; BRCA1: Breast cancer type 1 susceptibility protein; BRCA2: Breast cancer type 2 susceptibility protein; CADH1 E-Cadherin; CHD1: Chromodomain Helicase DNA Binding Protein 1; ERF: erythroblast transformation-specific 2 (ETS2) repressor factor; ERG: ETS-related gene; ETV1: ETS variant transcription factor 1; EZH2: Enhancer of zeste homolog 2; FOXA1: forkhead boxA1; IDH1: Isocitrate dehydrogenase 1; IDH1: Isocitrate dehydrogenase 1; KMT2A (MLL1): Lysine (K)-Specific Methyltransferase 2A; KMT2C (MLL3): Lysine (K)-Specific Methyltransferase 2C; KMT2D(MLL2): Lysine (K)-Specific Methyltransferase 2D; KDM1A (LSD1): Iysine (K)-specific demethylase 1A; KDM3A (JMKD1A): lysine (K)-specific demethylase 3A; KDM6A (UTX): lysine (K)-specific demethylase 6A; MYCN: N-mycproto-oncogene protein; NCOR1: Nuclear receptor corepressor 1; NCOR2: Nuclear receptor corepressor 2; NX3-1: Homeobox protein Nkx-3.1; PTEN: phosphatase and tensin homolog; RB1: Retinoblastoma1; SMAD4: SMAD family member 4; SPOP: Speckle-type POZ protein; TP53: tumor protein p53

PC biomarkers. MicroRNA-21, also known as miR21, mammalian miRNA encoded by the MIR21 gene located on chromosome 17, has been observed to suppress PTEN (tumor suppressor gene) in various cancers, such as colorectal and breast cancer, $[79,80]$ but no indication of its direct effects on PC. Yang et al. conducted an experiment on the effects of miR21 on PC cells using PC-3 cell lines, transfecting the cells with miR-21. They observed that in the presence of matured miR-21, which is generally conserved in mammalian cells, PC cells evade immune defence due to suppression of PTEN by miR-21, which results in cell growth and proliferation and eventually metastasis.[81] Based on the above-mentioned anal- ysis, miR-21 has been introduced as a PC biomarker, which needs further studies and possible epigenetic influence on cancer cells.

Up-regulation of miR-21 has been found to be correlated with down-regulation of miR-15 and mirR-16 as well as overexpression of TGF- $\beta$ signalling due to suppression of SMAD7 (Mothers against decapentaplegic homolog 7 leads to degradation of TGF- $\beta$ and inhibits hedgehog signalling), which leads to AR hyper-activation result in the bone lesion in PC.[82] Moreover, several studies showed the functional influence of miR-221 and miR-222 on tumorigenesis and cancer progression in various cancers, including PC.[83-86] In-vivo and in-vitro studies of PC3 cells 
have shown that reduction of cancer cell proliferation occurs when PC cells are induced with miR-221 and miR-222 inhibitors, which implicates miR-221/222 increasing expression in PC and its metastasis. [87]

Other miRNAs expressed rather significant volume changes in response to tumurgenesis. To demonstrate, miR-152-3p in LNCaP and PC3 were analyzed in vitro. The result indicated a low miR-152-3p level of tumour cells compared to healthy control cells. However, the same analysis experimented with the effects of highlevelmiR-152-3p mimic on tumour cells, which resulted in a great deal of proliferation and metastasis presenting external effects of the above-mentioned miRNA on tumurogenesis. [88] In addition to miRNA's direct effect on tumour progression, their function harbours inactivation or reduction of tumursupressors, such as tetraspanin, particularly tetraspanin $\mathrm{CD} 4$, which is found to suppress tumor progression and metastasis. In-vitro studies of miR-518f-5p on PC3 cells proved their down-regulating effects on $\mathrm{CD} 4$ leading to cancer progression and metastasis. [89] Table 4 shows that the role of miRNAs in PC.

In PC cancer patients, cfDNA (cell-free DNA) is released from apoptotic cells as nucleosomes from both healthy and diseased tissue that includes tumor cells, as well as microbial nucleic acids from systemic infections. [107] The regional chromosomal ploidy heterogeneity detected in cfDNA is an early indicator of progressive genomic instability. The following result indicated that cfDNA in serum could be used as a remarkable biomarker to distinguish PC from benign prostatic hypertrophy and prostatitis.[108]

\section{Prostate Cancer Therapy}

Over the past few decades, PC has attracted the attention of researchers working in this area considering its mortality rate in men, specifically in developed countries. Therefore, efforts have increased towards an efficient means of therapy. $[109,110]$

\section{Apoptosis as a Cancer Therapy (Apoptosis as Thera- peutic means in PC?)}

One of the major observations on cancer cells is their evasion from apoptosis. Studies demonstrate the presence of Fas and FasL (Fas ligand) mediating apoptosis in PC cells. However, resistance to such apoptosis was observed. [109,110] Various in-vitro studies on PC cells show an increase in FADD (Fas-associated protein with death domain) and eventual apoptosis using 5-Azacitine combined with BCLT (bicalutamide) to guide the cancer cells to death path and block further progress and metastasis.[76]

\begin{tabular}{|c|c|c|}
\hline miRNA & Roles in pathogenesis & Type \\
\hline $\operatorname{miR}-145[90,91]$ & Apoptosis, Metastasis & Dysregulation tumor supressor \\
\hline Let7c [92] & Apoptosis, cell proliferation, cell cycle & Dysregulation tumor supressor \\
\hline miR-125b $[93,94]$ & Apoptosis, tumor stage and & Dysregulation tumor supressor \\
\hline (p53 and PUMA targeted by miR-125b) & perineural invasion status & \\
\hline miR-221/222 [92] & Metastasis, cell cycle & Dysregulation tumor supressor \\
\hline \multicolumn{3}{|l|}{ (3' UTR of ARH1 targeted by miR-222) } \\
\hline miR-21 [95] & Invasion, metastasis, apoptosis & Dysregulation tumor supressor \\
\hline $\begin{array}{l}\text { miR-106a (cluster resides at Xq26.2 } \\
\text { chromosomal localization) [92] }\end{array}$ & Cell cycle & Dysregulation tumor supressor \\
\hline miR-27a (cluster resides at chromosome 19) [96] & Cell proliferation & $\begin{array}{l}\text { Upregulations result in the } \\
\text { downregulation of prohibitin }\end{array}$ \\
\hline miR-34c (localized at chromosome 11q23) $[97,98,99]$ & Metastasis & Dysregulated tumor supressor \\
\hline miR-205 [100] & & Downregulation \\
\hline $\operatorname{miR}-29[101]$ & $\begin{array}{l}\text { targets DNA methyl transferases } \\
\text { either directly or indirectly }\end{array}$ & $\begin{array}{c}\text { Silenced tumor supressor } \\
\text { genes }\end{array}$ \\
\hline miR-221 [102] & Tumor progression and metastasis & Downregulation \\
\hline miR-203 [103] & metastasis & $\begin{array}{l}\text { Regulates the expressipn of } \\
\text { prometastatic genes }\end{array}$ \\
\hline miR-375, miR-9, miR-141, miR-200b, miR-516a-39 [104] & Potential roles in prognosis? & Potential roles in prognosis? \\
\hline miR-26a, miR-195, let7 $[105,106]$ & Potential roles in prognosis? & Potential roles in prognosis? \\
\hline
\end{tabular}


Genetic Material into a Target Cell as Cancer Therapy

Gene therapy, defined as the introduction of genetic material into a target cell for therapeutic benefit, is a very promising treatment for many diseases, including cancer. To date, more than 2000 clinical trials employing gene transfer have taken place, and in general, many vehicles or vectors have been established as safe. $[111,112]$ Various techniques and approaches are employed to target the altered genes in PC, such as using siRNA (small interfering RNA), antisense oligonucleotides and plasmid DNA, along with chemotherapy to achieve PC apoptosis and overcome multidrug resistance conditions that arise from various drug-therapies.[113,114]

\section{Re-activation of Tumor Growth as a Cancer Therapy} In prostate tumours, re-activation of tumor growth has been observed in receptor-dependent androgen state, which may induce apoptosis of these cells by pro-apoptotic over-expressing tumor necrosis factor (TNF).[115] At the same time silence anti-apoptotic c-FLIP, allowing the development of a pro-apoptotic therapy which acts downstream and independently of androgen receptor (AR) signalling.[115] Analysis of PC cells has shown that the cells that express resistance towards castration-therapy also express a lower degree of polyphosphate-4-phosphatase type II (INPP4B), whose function includes potential tumor suppressor and a cascade activation which results in the negative control of phosphatidylinositol 3-kinase (PI3K) pathway leading to inhibition of cell malignant transformation. To prove the following findings, the PC cell line was transfected with the INPP4B gene, which evidently demonstrated a significant reduction in cancer cell viability and in a decrease in pAKT levels that down-regulates the PI3K pathway.[116] In addition to previous findings, some research experimented effects of an RNA-aptamer by transferring it into LNCaP and PC-3 and observed expression of genes that are observed phenotypically in normal prostate cells leading PC cells towards the apoptosis path and anti-proliferation mechanism and an eventually positive prognosis.[117]

\section{Gene Editing and Activation Tumor suppressor Genes with Silencing RNA}

Short interfering or silencing RNA (siRNA) was found to enhance the gene editing and activation of tumor suppressor genes and suppression of anti-apoptotic proteins in PC therapy. In a study, they transfected PC cell lines with siRNA molecules, treated with atecol- lagen, which facilitates the absorption of siRNA into tumor cells. The aim of this experiment was to reduce expression anti-apoptotic protein Bcl-xL, which is over expressed in PC both in vitro and in vivo. [118] Moreover, viruses have been found to express a rather efficient tool as vectors in PC therapy for the purpose of gene editing. For instance, baculoviruses are tested to deliver genes in a variety of tissues and cells, including benign prostate and PC cells line. Moreover, they can introduce therapeutic genes into dividing or quiescent cells, indicating that it might also act in tumor stem cells of PC.[119]

\section{Adenoviral Vector- mediated Gene Therapy}

Some other studies observed the effects of adenoviral vector- mediated gene therapy followed by radiotherapy, which was applied to 178-2 BMA and TSUPr1 cells in vitro to observe the colony formation of cells and their apoptosis process which led to tumor control with higher efficiency.[120]

Arafat et al. experimented the same combined (adenovirus and radiotherapy) or sole effect of using other types of adenoviruses as a vector (TRA-8 or Ad TRAIL (adenoviral encoding TRAIL)) in Human PC cell lines (LNCaP, PC-3 and DU-145) in vitro and colony-forming assay and RT-PCR were employed to determine cells' growth and genetic changes. In addition to in vitro studies, in vivo study using murine injected subcutaneously with PC cells was carried out which presented higher efficiency and lower cancer cell survival in combination therapy (vector combined with radiotherapy) rather than single treatment only Evaluated by elevation of BAX protein (responsible for apoptosis) and eventually apoptosis of cancer cells.[121]

\section{miRNAs as Therapeutic Means in PC}

As previously discussed, miRNAs play a vital role in PC recognition and diagnosis. However, their function is far more than just a biomarker. Various studies analyzed different miRNAs' effects in the treatment of PC in-vitro, in vivo and in silico.[122] The function of mature miRNA is achieved by seed sequence (short sequence located upstream of $5^{\prime}$ end of miRNA) in miRNA, which binds to the complementary motif in UTR (untranslated region) of targeted mRNA. For miRNA to be a target of therapy, they must present adequate stability inside and outside the cells, as well as show pharmacokinetic factors which would be appropriate to cell and environmental condition in vitro and in vivo. Different approaches have been designed and considered to use miRNA in PC therapy by either 
using complementary oligonucleotides targeting and preventing the function of specific miRNA [123,124] or transfecting PC cells with multiple miRNA-specific complementary sequences harboured in vector.[125]

ASOs (antisense oligonucleotides) via liposomal complexes and SMIR (small molecule inhibitors of miRNAs), which are designed based on the function of other molecules used for other disease therapies. They are used to target miRNAs. miRNAs have the ability to inhibit function other miRNAs that express the same see sequence, which is not seen with ASOs and is considered as an advantage of using miRNAs over antisense oligonucleotides. The SMIR approach aims to find compounds that bind and subsequently decrease the levels of mature miRNAs; however, such compounds can principally function to prevent transcription.[126]

Scientists designed other types of miRNA, known as miRNA sponge, which consists of numbers of binding sites (4-10) containing antisense or mismatched nucleotides, which will result in cleavage by argonaute RNA-induced silencing complex (RISC) when completely base-paired. The efficacy of miRNA sponge lies in two factors as follows: the binding site affinity and the ratio of miRNA sponge concentration to the ratio of mRNA targets.[126] PC cells were transfected with sponge miRNAs using plasmid in vitro and viral vector in vivo and a reporter gene for monitoring the functional changes and their actions on target miRNAs. [127] Some groups tested various sponge miRNAs and found that most of them, specifically pseudogenes, function as ceRNAs. They compete with target mRNAs for miRNA binding, making them endogenous sponges. The Phosphatase and tensin homolog (PTEN) pseudogene was the first demonstrated example, but since then, other pseudogenes and long non-coding RNAs have been shown to be valid ceRNAs. $[128,129]$ However, various pseudogenes demonstrated particularly different functions in cancer cells. For instance, NANOGP8 pseudogene is responsible for malignancy and metastasis and PC, and research studies indicate that the knock-out or deactivation of this pseudogene can benefit from the positive prognosis of PC therapy greatly.[130]

Studies have reported miR-185 as a tumor suppressor factor, was observed to be down-regulated in PC. Therefore, studies have been carried out to present miR-185 as a therapeutic mean for PA. miR-185, used along with bromodomain 8 isoform 2 (BRD8 ISO2) on PC3 and LNCaP, inhibited expression of androgen receptors (AR) directly by binding to the 3'- UTR region of AR mRNA.[131] Among several known miRNAs, the let-7 family is proved to play a significant rule in PC progress by regulating CSCs. BR-DIM upregulates the expression of the let-7 family, consequently downregulating the expression of EZH2 both in PC cell lines and human PC cells in the tissue. These results suggest that BR-DIM could serve as a novel agent for the inhibition of PC progression and recurrence.[132]

In addition to miRNA therapy, immunotherapy has expressed quite impressive results in cancer therapy that include vaccine therapy, which was administered in 2012 using the DNA fusion vaccine in PC cases. The designed vaccine consisted of the domain (DOM) from fragment $\mathrm{C}$ of tetanus toxin linked to an HLAA2-binding epitope from prostate-specific membrane antigen (PSMA) and induced DOM-specific CD4 and PSMA-specific CD8 $\mathrm{T}$ cells, generating anti-PSMA responses in most of the individuals suffering from PC.[133] 3D cell culture, as an in vitro condition, was proposed to be beneficiary in PA. In 2015, scientists designed a 3D cell culture model of PC bone metastasis in which collagen-based scaffolds were employed for a more efficient physiological microenvironment and helped to deliver siRNA to PC cells (PC3), which result in the alternative for PC bone metastases treatment. [134] Other researchers used aptamers along with 3D cultures as an efficient therapeutic way for PC. In 2016, scientists used eight aptamers with $3 \mathrm{D}$ cell culture for PC therapy.[117,135]

Studies about preventing activation of HDAC enzymes with HDAC inhibitors are carried out. HDAC inhibitors precluding activation of the HDAC enzyme may change gen expression. Recent cancer studies showed that inhibition of HDAC enzymes activate inactive G2 checkpoint starts apoptosis. Cell stimulated for apoptosis is stopped in G1 and G2 phases. Thus, cell proliferation is blocked.[136-140]

miRNA expression has an important role in HDAC enzyme functions. Studies showed that with HDAC inhibitors affected the miRNA expression levels.(Table 5).[141]

\section{Current Studies in PC: CRISPR-Cas System (CRISPR-Cas as Therapeutic Means in PC)}

CRISPR-Cas is a system that prokaryotes ( $84 \%$ archaea and $45 \%$ bacteria) ensure gaining adaptive immunity against viruses.[145] This system is composed of clustered regularly interspaced short palindromic repeats (CRISPR) and cas gene that is consist of similar sequence to gene families many nuclease and helicase.[146]

The system works via RNA. Therefore, this system is called an immune system via RNA.[147] When bacte- 
Table 5 miRNA expression affecting from HDACi and their mechanisms

\begin{tabular}{|c|c|c|c|}
\hline HDACi & Cell Type & MiRNA expression & Mechanism \\
\hline $\begin{array}{l}\text { MGCD0103 } \\
(0.5,1,2.5 \mathrm{IM})\end{array}$ & Prostate cancer (Panc1) & $\begin{array}{c}\text { miRNA-141, 203, } \\
\text { 200a, 200b, 200c } \\
\text { (up regulation) }\end{array}$ & $\begin{array}{c}\mathrm{H} 3 \text { ve } \mathrm{H} 4 \text { acetylation } \\
\mathrm{H} 3, \mathrm{H} 4 \mathrm{H} 3 \mathrm{~K} 9 \text { acetylation } \\
\text { and } \mathrm{H} 3 \mathrm{~K} 4 \mathrm{me} 3 \text { metylation } \\
\text { (upregülation) [142] }\end{array}$ \\
\hline TSA (300 nM); 5-azaCdR (1IM) & $\begin{array}{c}\text { Prostate cancer (PC-3, } \\
\text { LNCaP, DU145, 22Rv1, } \\
\text { LAPC-4, VCa) }\end{array}$ & $\begin{array}{c}\text { miRNA-9-5p, 9-3p, 27a, } \\
\text { 32, 33a, 34a, 132, 149, } \\
\text { 183, 188, 192, 193b, } \\
\text { 194, 203, 215, 218, 370, } \\
375,376 a, 449 a, 487 b \\
\text { 512-3p, 512-5p, 513a, } \\
\text { 515-5p, 517a, 517b, 517c, } \\
518 b, 520 f, 526 a, 572 \\
601,629,630,638,663,765\end{array}$ & $\begin{array}{c}\text { CpG island } \\
\text { methylation [143] }\end{array}$ \\
\hline $\begin{array}{l}\text { TSA (0.3 IM); Genistein } \\
\text { (25 IM); 5-aza (5 IM) }\end{array}$ & Prostate cancer (PC3) & MiRNA-145 & Not reported [144] \\
\hline
\end{tabular}

HDACi: Histone deacetylase inhibitor

Table 6 Studies regarding PC benefited from the system of the CRISPR-Cas

\section{Title of the Paper}

$\mathrm{N}$-Myc promotes therapeutic resistance development of neuroendocrine prostate cancer by differentially regulating miR-421/ATM pathway [151] CRISPR/Cas9 offers a new tool for studying the role of chromatin architecture in disease pathogenesis [152]

Generation of PTEN knockout (-/-) murine prostate cancer cells using the CRISPR/Cas9 system and comprehensive gene expression profiling. [153] FOXA1 knock-out via CRISPR/Cas9 altered Casp-9, Bax, CCND1, CDK4, and fibronectin expressions in LNCaP cells [154] A Somatically Acquired Enhancer of the Androgen Receptor Is a Noncoding Driver in Advanced Prostate Cancer. [155] Organelle-Derived Acetyl-CoA Promotes Prostate Cancer Cell Survival Migration, and Metastasis via Activation of Calmodulin Kinase II [156] Interleukin-30/IL27p28 Shapes Prostate Cancer Stem-like Cell Behavior and Is Critical for Tumor Onset and Metastasization [157]

Knocking-out of HIF1a gene by CRISPR/cas9 inhibits proliferation and invasiveness of prostate cancer DU145 cells [158]

CRISPR/Cas9 targeting of the androgen receptor suppresses the growth of LNCaP human prostate cancer cells [159] Store-operated calcium entry is dispensable for the activation of the ERK1/2 pathway in prostate cancer cells. [160]

Genome-wide CRISPR screen identifies HNRNPL as a prostate cancer dependency regulating RNA splicing. [161]

Protecting PTEN in the Nucleus. [162]

Targeted delivery of CRISPR/Cas9 to prostate cancer by modified gRNA using a flexible aptamer-cationic liposome. [163]

RNase $L$ is a negative regulator of cell migration [164] CRISPR/Cas9-mediated gene knockout of NANOG and NANOGP8 decreases the malignant potential of prostate cancer cells. [130]

\section{Method}

CRISPR-Cas9 was used to knock out.

CRISPR-Cas9 was used to base editing.

CRISPR-Cas9 was used to knock out.

CRISPR-Cas9 was used to knock out.

CRISPR-Cas9 was used to create insertions and deletions

CRISPR-Cas9 was used to create deletions.

CRISPR-Cas9 was used to knock out.

CRISPR-Cas9 was used to knock out.

Androgen genes were targeted in androgen-positive prostate cancer cells with CRISPR-Cas9 system.

CRISPR-Cas9 was used to knock out.

CRISPR-Cas9 was used to knock out.

CRISPR-Cas9 was used to knock out. CRISPR-Cas9 was used to knock out.

CRISPR-Cas9 was used to knock out. CRISPR-Cas9 was used to knock out. 
riophage infects bacteria, bacteria recognize the PAM (protospacer adjacent motif) sequence that belongs to bacteriophage via RNA. When bacteriophage infects bacteria, bacteria recognize the PAM sequence that belongs to bacteriophage via RNA. Consequently, the PAM region is cut by a cas enzyme showing endonuclease property. Information of the cutted region is attached above-mentioned among palindromic repeats. Thus, bacterium gains immunity memory against that virus. Pathogen property of the virus disappears with cutting the PAM region. [145,148]

The double-strand break occurs in target DNA. Because there is no compensation for this situation, the virus loses its function. Scientists have developed applications, such as gene silencing [with double-strand break] (knock out) and gene splice [with a donor constituting homology to target DNA sequence] (knock-in) using this property of the system. Thus, the CRISPR-Cas system is an inspiration for diagnosis and treatment in hereditary diseases, such as cancer. Consequently, change of arrays, such as insertion and deletion, in the gene region which they want to work is possible.[149,150] In Table 6, studies of PC benefited from the system of CRISPR-Cas are shown.

\section{Conclusion}

Current statistics show that approximately one in nine men is diagnosed with PC during their lifetime. Although PC can be a severe disease, luckily, most men diagnosed with PC do not die of PC. More than 2.9 million men in the United States who have been diagnosed with PC at some point are still alive today.

Genetic mutations are known to give rise to cancer. The epigenetic mechanisms which increase importance day by day and affect the structure of DNA play an important role in the pathogenesis of cancer.

As we understand the epigenetic mechanisms of PC better, we better modelling, which becomes a success in treatment will be.

miRNAs play a role in the epigenetic mechanism of cancer. When considering studies, we are clearly seen an important role in the therapeutic applications for PC.

Studies on the pathogenesis of the disease can be summarized in two steps as follows:

a. Modelling to better understand the pathogenesis of the disease.

b. Design of the therapeutic studies with different options for the treatment of the disease in consideration of the modelling.

The information which we have on the effects of epigenetic mechanisms involved in the progress of cancer is not yet at the desired level.

In particular, the use of miRNAs as a biomarker for therapies that are developed based on affecting epigenetic mechanisms is far away from the desired level. Thus, cohort studies that include genomic and epigenetic analyses are needed.

Peer-review: Externally peer-reviewed.

Conflict of Interest: Authors declare no conflict of interest.

Financial Support: No financial support has been used for this study.

\section{References}

1. Maitland NJ. Stem Cells in the Normal and Malignant Prostate. In: Tindall DJ, editor. Prostate Cancer-Biochemistry, Molecular Biology and Genetics. New York: Springer; 2013. p. 3-41.

2. Capasso LL. Antiquity of cancer. Int J Cancer 2005;113(1):2-13.

3. Lilja H, Ulmert D, Vickers AJ. Prostate-specific antigen and prostate cancer: prediction, detection and monitoring. Nat Rev Cancer 2008;8(4):268-78.

4. Borgoño CA, Diamandis EP. The emerging roles of human tissue kallikreins in cancer. Nat Rev Cancer 2004;4(11):876-90.

5. Shaw JL, Diamandis EP. Distribution of 15 human kallikreins in tissues and biological fluids. Clin Chem 2007;53(8):1423-32.

6. Wang MC, Valenzuela LA, Murphy GP, Chu TM. Purification of a human prostate specific antigen. Invest Urol 1979;17(2):159-63.

7. Lilja H, Oldbring J, Rannevik G, Laurell CB. Seminal vesicle-secreted proteins and their reactions during gelation and liquefaction of human semen. J Clin Invest 1987;80(2):281-5.

8. Gupta N, Sudhakar DVS, Gangwar PK, Sankhwar SN, Gupta NJ, Chakraborty B, et al. Mutations in the prostate specific antigen (PSA/KLK3) correlate with male infertility. Sci Rep 2017;7(1):11225.

9. Emami N, Deperthes D, Malm J, Diamandis EP. Major role of human KLK14 in seminal clot liquefaction. J Biol Chem 2008;283(28):19561-9.

10. Frame FM, Maitland NJ Cancer stem cells, models of study and implications of therapy resistance mechanisms. Adv Exp Med Biol 2011;720:105-18.

11. Greenberg R. Does prostate cancer represent more than one cancer? In: Prostate Cancer: Science and Clinical Practice. Mydlo JH, Godec CJ, editors. 1st edition. San Diego: Academic Press; 2003. p. 29-34. 
12. Robinson EJ, Neal DE, Collins AT. Basal cells are progenitors of luminal cells in primary cultures of differentiating human prostatic epithelium. Prostate 1998;37(3):149-60.

13. Isaacs JT, Coffey DS. Etiology and disease process of benign prostatic hyperplasia. Prostate Suppl 1989;2:33-50.

14. Richardson GD, Robson CN, Lang SH, Neal DE, Maitland NJ, Collins AT. CD133, a novel marker for human prostatic epithelial stem cells. J Cell Sci 2004;117(Pt 16):3539-45.

15. Demichelis F, Stanford JL. Genetic predisposition to prostate cancer: Update and future perspectives. Urol Oncol 2015;33(2):75-84.

16. Swierczynski S, Klieser E, Illig R, Alinger-Scharinger B, Kiesslich T, Neureiter D. Histone deacetylation meets miRNA: epigenetics and post-transcriptional regulation in cancer and chronic diseases. Expert Opin Biol Ther 2015;15(5):651-64.

17. Bacalini MG, Friso S, Olivieri F, Pirazzini C, Giuliani C, Capri M, et al. Present and future of anti-ageing epigenetic diets. Mech Ageing Dev 2014;136-137:101-15.

18. Denis H, Ndlovu MN, Fuks F. Regulation of mammalian DNA methyltransferases: a route to new mechanisms. EMBO Rep 2011;12(7):647-56.

19. Eckhardt F, Lewin J, Cortese R, Rakyan VK, Attwood $J$, Burger $M$, et al. DNA methylation profiling of human chromosomes 6, 20 and 22. Nat Genet 2006;38(12):1378-85.

20. Singh PK, Campbell MJ. The Interactions of microRNA and Epigenetic Modifications in Prostate Cancer. Cancers (Basel) 2013;5(3):998-1019.

21. Bishop KS, Ferguson LR. The interaction between epigenetics, nutrition and the development of cancer. Nutrients 2015;7(2):922-47.

22. Holliday R. Epigenetics: a historical overview. Epigenetics 2006;1(2):76-80.

23. Theodore SC, Davis M, Zhao F, Wang H, Chen D, Rhim J, et al. MicroRNA profiling of novel African American and Caucasian Prostate Cancer cell lines reveals a reciprocal regulatory relationship of miR-152 and DNA methyltranferase 1. Oncotarget 2014;5(11):3512-25.

24. Wang YL, Wu S, Jiang B, Yin FF, Zheng SS, Hou SC. Role of MicroRNAs in prostate cancer pathogenesis. Clin Genitourin Cancer 2015;13(4):260-70.

25. Peterson CL, Laniel MA. Histones and histone modifications. Curr Biol 2004;14(14):R546-51.

26. Narlikar GJ, Fan HY, Kingston RE. Cooperation between complexes that regulate chromatin structure and transcription. Cell 2002;108(4):475-87.

27. Fenrick R, Hiebert SW. Role of histone deacetylases in acute leukemia. J Cell Biochem Suppl 1998;3031:194-202.
28. Lakshmaiah KC, Jacob LA, Aparna S, Lokanatha D, Saldanha SC. Epigenetic therapy of cancer with histone deacetylase inhibitors. J Cancer Res Ther 2014;10(3):469-78.

29. Noonan EJ, Place RF, Pookot D, Basak S, Whitson JM, Hirata $\mathrm{H}$, et al. miR-449a targets HDAC-1 and induces growth arrest in prostate cancer. Oncogene 2009;28(14):1714-24.

30. Eeles RA, Al Olama AA, Benlloch S, Saunders EJ, Leongamornlert DA, Tymrakiewicz $\mathrm{M}$, et al. Identification of 23 new prostate cancer susceptibility loci using the iCOGS custom genotyping array. Nat Genet 2013;45(4):385-91, 391e1-2.

31. Amin Al Olama A, Kote-Jarai Z, Schumacher FR, Wiklund F, Berndt SI, Benlloch S, et al. A meta-analysis of genome-wide association studies to identify prostate cancer susceptibility loci associated with aggressive and non-aggressive disease. Hum Mol Genet 2013;22(2):408-15.

32. Fitzgerald LM, Kwon EM, Conomos MP, Kolb S, Holt S, Levine D, et al. Genome-wide association study identifies a genetic variant associated with risk for more aggressive prostate cancer. Cancer Epidemiol Biomarkers Prev 2011;20(6):1196-203.

33. Grasso CS, Wu YM, Robinson DR, Cao X, Dhanasekaran SM, Khan AP, et al. The mutational landscape of lethal castration-resistant prostate cancer. Nature 2012;1487(7406):239-43.

34. Taplin SH, Barlow W, Urban N, Mandelson MT, Timlin DJ, Ichikawa L, et al. Stage, age, comorbidity, and direct costs of colon, prostate, and breast cancer care. J Natl Cancer Inst 1995;87(6):417-26.

35. Visakorpi T, Hyytinen E, Koivisto P, Tanner M, Keinänen $\mathrm{R}$, Palmberg $\mathrm{C}$, et al. In vivo amplification of the androgen receptor gene and progression of human prostate cancer. Nat Genet 1995;9(4):401-6.

36. Pritchard CC, Mateo J, Walsh MF, De Sarkar N, Abida W, Beltran H, et al. Inherited DNA-Repair Gene Mutations in Men with Metastatic Prostate Cancer. N Engl J Med 2016;375(5):443-53.

37. Fraser M, Sabelnykova VY, Yamaguchi TN, Heisler LE, Livingstone J, Huang V, et al. Genomic hallmarks of localized, non-indolent prostate cancer. Nature 2017;541(7637):359-64.

38. Mateo J, Carreira S, Sandhu S, Miranda S, Mossop H, Perez-Lopez R, et al. DNA-Repair Defects and Olaparib in Metastatic Prostate Cancer. N Engl J Med 2015;373(18):1697-708.

39. Robinson D, Van Allen EM, Wu YM, Schultz N, Lonigro RJ, Mosquera JM, et al. Integrative clinical genomics of advanced prostate cancer. Cell 2015;161(5):1215-28. 
40. Barbieri CE, Baca SC, Lawrence MS, Demichelis F, Blattner M, Theurillat JP, et al. Exome sequencing identifies recurrent SPOP, FOXA1 and MED12 mutations in prostate cancer. Nat Genet 2012;44(6):685-9.

41. Burkhardt L, Fuchs S, Krohn A, Masser S, Mader M, Kluth $\mathrm{M}$, et al. CHD1 is a $5 \mathrm{q} 21$ tumor suppressor required for ERG rearrangement in prostate cancer. Cancer Res 2013;73(9):2795-805.

42. Zhao D, Lu X, Wang G, Lan Z, Liao W, Li J, et al. Synthetic essentiality of chromatin re-modelling factor CHD1 in PTEN-deficient cancer. Nature 2017;542(7642):484-8.

43. Bose R, Karthaus WR, Armenia J, Abida W, Iaquinta PJ, Zhang Z, et al. ERF mutations reveal a balance of ETS factors controlling prostate oncogenesis. Nature 2017;546(7660):671-5.

44. Huang FW, Mosquera JM, Garofalo A, Oh C, Baco M, Amin-Mansour A, et al. Exome sequencing of AfricanAmerican prostate cancer reveals loss-of-function ERF mutations. Cancer Discov 2017;7(9):973-83.

45. Tomlins SA, Rhodes DR, Perner S, Dhanasekaran SM, Mehra R, Sun XW, et al. Recurrent fusion of TMPRSS2 and ETS transcription factor genes in prostate cancer. Science 2005;310(5748):644-8.

46. Sizemore GM, Pitarresi JR, Balakrishnan S, Ostrowski MC. The ETS family of oncogenic transcription factors in solid tumours. Nat Rev Cancer 2017;17(6):337-51.

47. $\mathrm{Xu} \mathrm{K,} \mathrm{Wu} \mathrm{ZJ,} \mathrm{Groner} \mathrm{AC,} \mathrm{He} \mathrm{HH,} \mathrm{Cai} \mathrm{C,} \mathrm{Lis} \mathrm{RT,}$ et al. EZH2 oncogenic activity in castration-resistant prostate cancer cells is Polycomb-independent. Science 2012;338(6113):1465-9.

48. Zhang C, Wang L, Wu D, Chen H, Chen Z, ThomasAhner JM, et al. Definition of a FoxA1 Cistrome that is crucial for G1 to S-phase cell-cycle transit in castration-resistant prostate cancer. Cancer Res 2011;71(21):6738-48.

49. Cancer Genome Atlas Research Network. The Molecular Taxonomy of Primary Prostate Cancer. Cell 2015;163(4):1011-25.

50. Malik R, Khan AP, Asangani IA, Cieślik M, Prensner JR, Wang X, et al. Targeting the MLL complex in castration-resistant prostate cancer. Nat Med 2015;21(4):344-52.

51. Beltran H, Prandi D, Mosquera JM, Benelli M, Puca L, Cyrta J, et al. Divergent clonal evolution of castrationresistant neuroendocrine prostate cancer. Nat Med 2016;22(3):298-305.

52. Sehrawat A, Gao L, Wang Y, Bankhead A 3rd, McWeeney SK, King CJ, et al. LSD1 activates a lethal prostate cancer gene network independently of its demethylase function. Proc Natl Acad Sci U S A 2018;115(18):E4179-88.
53. Fan L, Zhang F, Xu S, Cui X, Hussain A, Fazli L, et al. Histone demethylase JMJD1A promotes alternative splicing of AR variant 7 (AR-V7) in prostate cancer cells. Proc Natl Acad Sci U S A 2018;115(20):E4584-93.

54. Beltran H, Rickman DS, Park K, Chae SS, Sboner A, MacDonald TY, et al. Molecular characterization of neuroendocrine prostate cancer and identification of new drug targets. Cancer Discov 2011;1(6):487-95.

55. Dardenne E, Beltran H, Benelli M, Gayvert K, Berger A, Puca L, et al. N-Myc Induces an EZH2-Mediated Transcriptional Program Driving Neuroendocrine Prostate Cancer. Cancer Cell 2016;30(4):563-77.

56. Lee JK, Phillips JW, Smith BA, Park JW, Stoyanova T, McCaffrey EF, et al. N-Myc Drives Neuroendocrine Prostate Cancer Initiated from Human Protate Epithelial Cells. Cancer Cell 2016;29(4):536-47.

57. Hodgson MC, Astapova I, Cheng S, Lee LJ, Verhoeven $\mathrm{MC}$, Choi E, et al. The androgen receptor recruits nuclear receptor CoRepressor $(\mathrm{N}-\mathrm{CoR})$ in the presence of mifepristone via its $\mathrm{N}$ and $\mathrm{C}$ termini revealing a novel molecular mechanism for androgen receptor antagonists. J Biol Chem 2005;280(8):6511-9.

58. Taylor BS, Schultz N, Hieronymus H, Gopalan A, Xiao Y, Carver BS, et al. Integrative genomic profiling of human prostate cancer. Cancer Cell 2010;18(1):11-22.

59. He WW, Sciavolino PJ, Wing J, Augustus M, Hudson P, Meissner PS, et al. A novel human prostate-specific, androgen-regulated homeobox gene (NKX3.1) that maps to $8 \mathrm{p} 21$, a region frequently deleted in prostate cancer. Genomics 1997;43(1):69-77.

60. Bhatia-Gaur R, Donjacour AA, Sciavolino PJ, Kim M, Desai N, Young P, et al. Roles for Nkx3.1 in prostate development and cancer. Genes Dev 1999;13(8):966-77.

61. Wang S, Gao J, Lei Q, Rozengurt N, Pritchard C, Jiao $\mathrm{J}$, et al. Prostate-specific deletion of the murine Pten tumor suppressor gene leads to metastatic prostate cancer. Cancer Cell 2003;4(3):209-21.

62. Ku SY, Rosario S, Wang Y, Mu P, Seshadri M, Goodrich ZW, et al. Rb1 and Trp53 cooperate to suppress prostate cancer lineage plasticity, metastasis, and antiandrogen resistance. Science 2017;355(6320):78-83.

63. Ding Z, Wu CJ, Chu GC, Xiao Y, Ho D, Zhang J, et al. SMAD4-dependent barrier constrains prostate cancer growth and metastatic progression. Nature 2011;470(7333):269-73.

64. Wang G, Lu X, Dey P, Deng P, Wu CC, Jiang S, et al. Targeting YAP-Dependent MDSC Infiltration Impairs Tumor Progression. Cancer Discov 2016;6(1):80-95.

65. Theurillat JP, Udeshi ND, Errington WJ, Svinkina T, Baca SC, Pop M, et al. Prostate cancer. Ubiquitylome analysis identifies dysregulation of effector 
substrates in SPOP-mutant prostate cancer. Science 2014;346(6205):85-89.

66. Blattner M, Liu D, Robinson BD, Huang D, Poliakov A, Gao D, et al. SPOP Mutation Drives Prostate Tumorigenesis In Vivo through Coordinate Regulation of PI3K/mTOR and AR Signaling. Cancer Cell 2017;31(3):436-51.

67. Mu P, Zhang Z, Benelli M, Karthaus WR, Hoover E, Chen CC, et al. SOX2 promotes lineage plasticity and antiandrogen resistance in TP53- and RB1-deficient prostate cancer. Science 2017;355(6320):84-8.

68. Hellawell GO, Brewster SF. Growth factors and their receptors in prostate cancer. BJU Int 2002;89(3):230-40.

69. Jorda M, Morales A, Ghorab Z, Fernandez G, Nadji M, Block N. Her2 expression in prostatic cancer: a comparison with mammary carcinoma. J Urol 2002;168(4 Pt 1):1412-4.

70. Varambally S, Dhanasekaran SM, Zhou M, Barrette TR, Kumar-Sinha C, Sanda MG, et al. The polycomb group protein EZH2 is involved in progression of prostate cancer. Nature 2002;419(6907):624-9.

71. Taneja SS, Ha S, Garabedian MJ. Androgen stimulated cellular proliferation in the human prostate cancer cell line $\mathrm{LNCaP}$ is associated with reduced retinoblastoma protein expression. J Cell Biochem 2001;84(1):188-99.

72. Bálint E E, Vousden KH. Activation and activities of the p53 tumour suppressor protein. Br J Cancer 2001;85(12):1813-23.

73. Chappell WH, Lehmann BD, Terrian DM, Abrams SL, Steelman LS, McCubrey JA. p53 expression controls prostate cancer sensitivity to chemotherapy and the MDM2 inhibitor Nutlin-3. Cell Cycle 2012;11(24):4579-88.

74. Taplin ME. Androgen receptor: role and novel therapeutic prospects in prostate cancer. Expert Rev Anticancer Ther 2008;8(9):1495-508.

75. Takai D, Jones PA. Comprehensive analysis of $\mathrm{CpG}$ islands in human chromosomes 21 and 22. Proc Natl Acad Sci U S A 2002;99(6):3740-5.

76. Gravina GL, Marampon F, Di Staso M, Bonfili P, Vitturini A, Jannini EA, et al. 5-Azacitidine restores and amplifies the bicalutamide response on preclinical models of androgen receptor expressing or deficient prostate tumors. Prostate 2010;70(11):1166-78.

77. Urbanucci A, Sahu B, Seppälä J, Larjo A, Latonen $\mathrm{LM}$, Waltering KK, et al. Overexpression of androgen receptor enhances the binding of the receptor to the chromatin in prostate cancer. Oncogene 2012;31(17):2153-63.

78. Wahid F, Shehzad A, Khan T, Kim YY. MicroRNAs: synthesis, mechanism, function, and recent clinical trials. Biochim Biophys Acta 2010;1803(11):1231-43.
79. Yang Y, Guo JX, Shao ZQ. miR-21 targets and inhibits tumor suppressor gene PTEN to promote prostate cancer cell proliferation and invasion: An experimental study. Asian Pac J Trop Med 2017;10(1):87-91.

80. Sheng WZ, Chen YS, Tu CT, He J, Zhang B, Gao WD. MicroRNA-21 promotes phosphatase gene and protein kinase $\mathrm{B} /$ phosphatidylinositol 3-kinase expression in colorectal cancer. World J Gastroenterol 2016;22(24):5532-9.

81. Fragni M, Bonini SA, Bettinsoli P, Bodei S, Generali D, Bottini A, et al. The miR-21/PTEN/Akt signaling pathway is involved in the anti-tumoral effects of zoledronic acid in human breast cancer cell lines. Naunyn Schmiedebergs Arch Pharmacol 2016;389(5):529-38.

82. Bonci D, Coppola V, Patrizii M, Addario A, Cannistraci A, Francescangeli $F$, et al. A microRNA code for prostate cancer metastasis. Oncogene 2016;35(9):1180-92.

83. Chen WX, Hu Q, Qiu MT, Zhong SL, Xu JJ, Tang JH, et al. miR-221/222: promising biomarkers for breast cancer. Tumour Biol 2013;34(3):1361-70.

84. Hao J, Zhang C, Zhang A, Wang K, Jia Z, Wang $\mathrm{G}$, et al. miR-221/222 is the regulator of $\mathrm{Cx} 43$ expression in human glioblastoma cells. Oncol Rep 2012;27(5):1504-10.

85. Jikuzono T, Kawamoto M, Yoshitake H, Kikuchi K, Akasu $\mathrm{H}$, Ishikawa $\mathrm{H}$, et al. The miR-221/222 cluster, miR-10b and miR-92a are highly upregulated in metastatic minimally invasive follicular thyroid carcinoma. Int J Oncol 2013;42(6):1858-68.

86. Sun T, Wang Q, Balk S, Brown M, Lee GS, Kantoff P. The role of microRNA-221 and microRNA-222 in androgen-independent prostate cancer cell lines. Cancer Res 2009;69(8):3356-63.

87. Yang X, Yang Y, Gan R, Zhao L, Li W, Zhou H, et al. Down-regulation of mir-221 and mir-222 restrain prostate cancer cell proliferation and migration that is partly mediated by activation of SIRT1. PLoS One 2014;9(6):e98833.

88. Matin F, Jeet V, Moya L, Selth LA, Chambers S; Australian Prostate Cancer BioResource, et al. A Plasma Biomarker Panel of Four MicroRNAs for the Diagnosis of Prostate Cancer. Sci Rep 2018;8(1):6653.

89. Bond DR, Naudin C, Carroll AP, Goldie BJ, Brzozowski JS, Jankowski HM, et al. miR-518f-5p decreases tetraspanin CD9 protein levels and differentially affects non-tumourigenic prostate and prostate cancer cell migration and adhesion. Oncotarget 2017;9(2):1980-91.

90.Penson RT, Oliva E, Skates SJ, Glyptis T, Fuller AF Jr, Goodman A, et al. Expression of multidrug re- 
sistance-1 protein inversely correlates with paclitaxel response and survival in ovarian cancer patients: a study in serial samples. Gynecol Oncol 2004;93(1):98-106.

91. He L, He X, Lim LP, de Stanchina E, Xuan Z, Liang $\mathrm{Y}$, et al. A microRNA component of the p53 tumour suppressor network. Nature 2007;447(7148):1130-4.

92. Casanova-Salas I, Rubio-Briones J, Fernández-Serra A, López-Guerrero JA. miRNAs as biomarkers in prostate cancer. Clin Transl Oncol 2012;14(11):803-11.

93. Enomoto Y, Kitaura J, Hatakeyama K, Watanuki J, Akasaka T, Kato N, et al. E $\mu / m i R-125 b$ transgenic mice develop lethal B-cell malignancies. Leukemia 2011;25(12):1849-56.

94. Feng B, Wang R, Chen LB. Review of miR-200b and cancer chemosensitivity. Biomed Pharmacother 2012;66(6):397-402.

95. Lu Z, Liu M, Stribinskis V, Klinge CM, Ramos KS, Colburn NH, et al. MicroRNA-21 promotes cell transformation by targeting the programmed cell death 4 gene. Oncogene 2008;27(31):4373-9.

96. Porkka KP, Pfeiffer MJ, Waltering KK, Vessella RL, Tammela TL, Visakorpi T. MicroRNA expression profiling in prostate cancer. Cancer Res 2007;67(13):6130-5.

97. Dahiya R, McCarville J, Lee C, Hu W, Kaur G, Carroll P, et al. Deletion of chromosome 11p15, p12, q22, q23-24 loci in human prostate cancer. Int J Cancer 1997;72(2):283-8.

98. Ellsworth RE, Vertrees A, Love B, Hooke JA, Ellsworth DL, Shriver CD. Chromosomal alterations associated with the transition from in situ to invasive breast cancer. Ann Surg Oncol 2008;15(9):2519-25.

99. Rasio D, Negrini M, Manenti G, Dragani TA, Croce CM. Loss of heterozygosity at chromosome $11 \mathrm{q}$ in lung adenocarcinoma: identification of three independent regions. Cancer Res 1995;55(18):3988-91.

100.Majid S, Dar AA, Saini S, Yamamura S, Hirata $\mathrm{H}$, Tanaka Y, et al. MicroRNA-205-directed transcriptional activation of tumor suppressor genes in prostate cancer. Cancer 2010;116(24):5637-49.

101.Fabbri M, Garzon R, Cimmino A, Liu Z, Zanesi N, Callegari E, et al. MicroRNA-29 family reverts aberrant methylation in lung cancer by targeting DNA methyltransferases 3A and 3B. Proc Natl Acad Sci U S A 2007;104(40):15805-10.

102.Chen Y, Zaman MS, Deng G, Majid S, Saini S, Liu J, et al. MicroRNAs 221/222 and genistein-mediated regulation of ARHI tumor suppressor gene in prostate cancer. Cancer Prev Res (Phila) 2011;4(1):76-86.

103.Saini S, Majid S, Shahryari V, Arora S, Yamamura S, Chang I, et al. miRNA-708 control of
CD44(+) prostate cancer-initiating cells. Cancer Res 2012;72(14):3618-30.

104.Brase JC, Johannes M, Schlomm T, Fälth M, Haese A, Steuber T, et al. Circulating miRNAs are correlated with tumor progression in prostate cancer. Int J Cancer 2011;128(3):608-16.

105.Mahn R, Heukamp LC, Rogenhofer S, von Ruecker A, Müller SC, Ellinger J. Circulating microRNAs (miRNA) in serum of patients with prostate cancer. Urology 2011;77(5):1265.e9-16.

106.Nadiminty N, Tummala R, Lou W, Zhu Y, Shi XB, Xou JX, et al. MicroRNA let-7c is downregulated in prostate cancer and suppresses prostate cancer growth. PLoS ONE 2012;7(3):e32832.

107.Beck J, Urnovitz HB, Riggert J, Clerici M, Schütz E. Profile of the circulating DNA in apparently healthy individuals. Clin Chem 2009;55(4):730-8.

108.Schütz E, Akbari MR, Beck J, Urnovitz H, Zhang WW, Bornemann-Kolatzki K, et al. Chromosomal instability in cell-free DNA is a serum biomarker for prostate cancer. Clin Chem 2015;61(1):239-48.

109.Liu QY, Rubin MA, Omene C, Lederman S, Stein CA. Fas ligand is constitutively secreted by prostate cancer cells in vitro. Clin Cancer Res 1998;4(7):1803-11.

110.Hyer ML, Voelkel-Johnson C, Rubinchik S, Dong J, Norris JS. Intracellular Fas ligand expression causes Fas-mediated apoptosis in human prostate cancer cells resistant to monoclonal antibody-induced apoptosis. Mol Ther 2000;2(4):348-58.

111. Nathwani AC, Tuddenham EG, Rangarajan S, Rosales C, McIntosh J, Linch DC, et al. Adenovirus-associated virus vector-mediated gene transfer in hemophilia B. N Engl J Med 2011;365(25):2357-65.

112. Simonelli F, Maguire AM, Testa F, Pierce EA, Mingozzi F, Bennicelli JL, et al. Gene therapy for Leber's congenital amaurosis is safe and effective through 1.5 years after vector administration. Mol Ther 2010;18(3):643-50.

113.Izquierdo M. Short interfering RNAs as a tool for cancer gene therapy. Cancer Gene Ther 2005;12(3):217-27.

114.Li J, Wang Y, Zhu Y, Oupický D. Recent advances in delivery of drug-nucleic acid combinations for cancer treatment. J Control Release 2013;172(2):589-600.

115. Nastiuk KL, Krolewski JJ. Opportunities and challenges in combination gene cancer therapy. Adv Drug Deliv Rev 2016;98:35-40.

116.Ding H, Sun Y, Hou Y, Li L. Effects of INPP4B gene transfection combined with PARP inhibitor on castration therapy-resistant prostate cancer cell line, PC3. Urol Oncol 2014;32(5):720-6.

117.Marangoni K, Neves AF, Rocha RM, Faria PR, Alves PT, Souza AG, et al. Prostate-specific RNA aptamer: 
promising nucleic acid antibody-like cancer detection. Sci Rep 2015;5:12090.

118.Mu P, Nagahara S, Makita N, Tarumi Y, Kadomatsu K, Takei Y. Systemic delivery of siRNA specific to tumor mediated by atelocollagen: combined therapy using siRNA targeting $\mathrm{Bcl}-\mathrm{xL}$ and cisplatin against prostate cancer. Int J Cancer 2009;125(12):2978-90.

119. Kaikkonen MU, Ylä-Herttuala S, Airenne KJ. How to avoid complement attack in baculovirus-mediated gene delivery. J Invertebr Pathol 2011;107 Suppl:S71-9.

120.Fujita T, Satoh T, Timme TL, Hirayama T, Zhu JX, Kusaka N, et al. Combined therapeutic effects of adenoviral vector-mediated GLIPR1 gene therapy and radiotherapy in prostate and bladder cancer models. Urol Oncol 2014;32(2):92-100.

121. Arafat W, Zhou T, Naoum GE, Buchsbaum DJ. Targeted radiotherapy potentiates the cytotoxicity of a novel anti-human DR5 monoclonal antibody and the adenovirus encoding soluble TRAIL in prostate cancer. J Egypt Natl Canc Inst 2015;27(4):205-15.

122.Ergün S. In silico analysis of biomarker potentials of miRNA-mediated ceRNAs in prostate cancer. Dicle Med J 2018;45(4):415-29.

123. Nielsen CB, Shomron N, Sandberg R, Hornstein E, Kitzman J, Burge CB. Determinants of targeting by endogenous and exogenous microRNAs and siRNAs. RNA 2007;13(11):1894-910.

124.Lewis BP, Burge CB, Bartel DP. Conserved seed pairing, often flanked by adenosines, indicates that thousands of human genes are microRNA targets. Cell 2005;120(1):15-20.

125.Ebert MS, Neilson JR, Sharp PA. MicroRNA sponges: competitive inhibitors of small RNAs in mammalian cells. Nat Methods 2007;4(9):721-6.

126.Deiters A. Small molecule modifiers of the microRNA and RNA interference pathway. AAPS J 2010;12(1):51-60.

127.Du C, Liu C, Kang J, Zhao G, Ye Z, Huang S, et al. MicroRNA miR-326 regulates TH-17 differentiation and is associated with the pathogenesis of multiple sclerosis. Nat Immunol 2009;10(12):1252-9.

128. Poliseno L, Marranci A, Pandolfi PP. Pseudogenes in Human Cancer. Front Med 2015;2:68.

129.Karreth FA, Reschke M, Ruocco A, Ng C, Chapuy $\mathrm{B}$, Léopold $\mathrm{V}$, et al. The BRAF pseudogene functions as a competitive endogenous RNA and induces lymphoma in vivo. Cell 2015;161(2):319-32.

130.Kawamura N, Nimura K, Nagano H, Yamaguchi S, Nonomura N, Kaneda Y. CRISPR/Cas9-mediated gene knockout of NANOG and NANOGP8 decreases the malignant potential of prostate cancer cells. Oncotarget 2015;6(26):22361-74.
131.Chen Z, Penet MF, Krishnamachary B, Banerjee SR, Pomper MG, Bhujwalla ZM. PSMA-specific theranostic nanoplex for combination of TRAIL gene and 5 -FC prodrug therapy of prostate cancer. Biomaterials 2016;80:57-67.

132.Kong D, Heath E, Chen W, Cher ML, Powell I, Heilbrun L, et al. Loss of let-7 up-regulates EZH2 in prostate cancer consistent with the acquisition of cancer stem cell signatures that are attenuated by BRDIM. PLoS One 2012;7(3):e33729.

133. Chudley L, McCann K, Mander A, Tjelle T, CamposPerez J, Godeseth R, et al. DNA fusion-gene vaccination in patients with prostate cancer induces high-frequency CD8(+) T-cell responses and increases PSA doubling time. Cancer Immunol Immunother 2012;61(11):2161-70.

134. Fitzgerald KA, Guo J, Tierney EG, Curtin CM, Malhotra M, Darcy R, et al. The use of collagen-based scaffolds to simulate prostate cancer bone metastases with potential for evaluating delivery of nanoparticulate gene therapeutics. Biomaterials 2015;66:53-66.

135.Souza AG, Marangoni K, Fujimura PT, Alves PT, Silva MJ, Bastos VA, et al. 3D Cell-SELEX: Development of RNA aptamers as molecular probes for PC-3 tumor cell line. Exp Cell Res 2016;341(2):147-56.

136. Marks PA, Miller T, Richon VM. Histone deacetylases. Curr Opin Pharmacol 2003;3(4):344-51.

137. Rosato RR, Grant S. Histone deacetylase inhibitors: insights into mechanisms of lethality. Expert Opin Ther Targets 2005;9(4):809-24.

138. Hrzenjak A, Moinfar F, Kremser ML, Strohmeier B, Staber PB, Zatloukal K, et al. Valproate inhibition of histone deacetylase 2 affects differentiation and decreases proliferation of endometrial stromal sarcoma cells. Mol Cancer Ther 2006;5(9):2203-10.

139. Taddei A, Roche D, Bickmore WA, Almouzni G. The effects of histone deacetylase inhibitors on heterochromatin: implications for anticancer therapy? EMBO Rep 2005;6(6):520-4.

140.Bernhard D, Ausserlechner MJ, Tonko M, Löffler M, Hartmann BL, Csordas A, et al. Apoptosis induced by the histone deacetylase inhibitor sodium butyrate in human leukemic lymphoblasts. FASEB J 1999;13(14):1991-2001.

141.Ali SR, Humphreys KJ, McKinnon RA, Michael MZ. Impact of Histone Deacetylase Inhibitors on microRNA Expression and Cancer Therapy: A Review. Drug Dev Res 2015;76(6):296-317.

142.Meidhof S, Brabletz S, Lehmann W, Preca BT, Mock $\mathrm{K}$, Ruh $\mathrm{M}$, et al. ZEB1-associated drug resistance in cancer cells is reversed by the class I HDAC inhibitor mocetinostat. EMBO Mol Med 2015;7(6):831-47. 
143. Rauhala HE, Jalava SE, Isotalo J, Bracken H, Lehmusvaara S, Tammela TL, et al. miR-193b is an epigenetically regulated putative tumor suppressor in prostate cancer. Int J Cancer 2010;127(6):1363-72.

144.Zaman MS, Chen Y, Deng G, Shahryari V, Suh SO, Saini S, et al. The functional significance of microRNA-145 in prostate cancer. $\mathrm{Br} \mathrm{J}$ Cancer 2010;103(2):256-64.

145. Rath D, Amlinger L, Rath A, Lundgren M. The CRISPR-Cas immune system: biology, mechanisms and applications. Biochimie 2015;117:119-28.

146.Jansen R, van Embden JD, Gaastra W, Schouls LM. Identification of a novel family of sequence repeats among prokaryotes. OMICS 2002;6(1):23-33.

147.Barrangou R, Fremaux C, Deveau H, Richards M, Boyaval P, Moineau S, et al. CRISPR provides acquired resistance against viruses in prokaryotes. Science 2007;315(5819):1709-12.

148.Bolotin A, Quinquis B, Sorokin A, Ehrlich SD. Clustered regularly interspaced short palindrome repeats (CRISPRs) have spacers of extrachromosomal origin. Microbiology 2005;151(Pt 8):2551-61.

149. Cong L, Ran FA, Cox D, Lin S, Barretto R, Habib N, et al. Multiplex genome engineering using CRISPR/Cas systems. Science 2013;339(6121):819-23.

150.Mali P, Yang L, Esvelt KM, Aach J, Guell M, DiCarlo JE, et al. RNA-guided human genome engineering via Cas9. Science 2013;339(6121):823-6.

151.Yin Y, Xu L, Chang Y, Zeng T, Chen X, Wang A, et al. N-Myc promotes therapeutic resistance development of neuroendocrine prostate cancer by differentially regulating miR-421/ATM pathway. Mol Cancer 2019;18(1):11.

152.Guo X, Dean A. CRISPR/Cas9 offers a new tool for studying the role of chromatin architecture in disease pathogenesis. Genome Biol 2018; 6;19(1):185.

153. Takao A, Yoshikawa K, Karnan S, Ota A, Uemura H, De Velasco MA, Kura, et al. Generation of PTEN knockout ( / ) murine prostate cancer cells using the CRISPR/Cas9 system and comprehensive gene expression profiling. Oncol Rep 2018;40(5):2455-66.

154. Albayrak G, Konac E, Ugras Dikmen A, Bilen CY. FOXA1 knock-out via CRISPR/Cas9 altered Casp9, Bax, CCND1, CDK4, and fibronectin expres- sions in LNCaP cells. Exp Biol Med (Maywood) 2018;243(12):990-4.

155.Takeda DY, Spisák S, Seo JH, Bell C, O’Connor E, Korthauer K, et al. A Somatically Acquired Enhancer of the Androgen Receptor Is a Noncoding Driver in Advanced Prostate Cancer. Cell 2018;174(2):422-32. e13.

156.Yu G, Cheng CJ, Lin SC, Lee YC, Frigo DE, Yu-Lee LY, et al. Organelle-Derived Acetyl-CoA Promotes Prostate Cancer Cell Survival, Migration, and Metastasis via Activation of Calmodulin Kinase II. Cancer Res 2018;78(10):2490-502.

157.Sorrentino C, Ciummo SL, Cipollone G, Caputo S, Bellone M, Di Carlo E, et al. Interleukin-30/IL27p28 Shapes Prostate Cancer Stem-like Cell Behavior and Is Critical for Tumor Onset and Metastasization. Cancer Res 2018;78(10):2654-68.

158.Xu Y, Xu M, Zhang M, Tan J, Su Z, Chen X, et al. Knocking-out of HIF1a gene by CRISPR/cas9 inhibits proliferation and invasiveness of prostate cancer DU145 cells. [Article in Chinese]. Zhonghua Yi Xue Yi Chuan Xue Za Zhi 2018;35(2):160-4.

159. Wei C, Wang F, Liu W, Zhao W, Yang Y, Li K, et al. CRISPR/Cas9 targeting of the androgen receptor suppresses the growth of LNCaP human prostate cancer cells. Mol Med Rep 2018;17(2):2901-6.

160.Lopez-Guerrero AM, Pascual-Caro C, MartinRomero FJ, Pozo-Guisado E. Store-operated calcium entry is dispensable for the activation of ERK1/2 pathway in prostate cancer cells. Cell Signal 2017;40:44-52.

161.Fei T, Chen Y, Xiao T, Li W, Cato L, Zhang P, et al. Genome-wide CRISPR screen identifies HNRNPL as a prostate cancer dependency regulating RNA splicing. Proc Natl Acad Sci 2017;114(26):5207-15.

162.Protecting PTEN in the Nucleus. Cancer Discov 2017;7(4):OF1.

163.Zhen S, Takahashi Y, Narita S, Yang YC, Li X. Targeted delivery of CRISPR/Cas9 to prostate cancer by modified gRNA using a flexible aptamer-cationic liposome. Oncotarget 2017;8(6):9375-87.

164. Banerjee S, Li G, Li Y, Gaughan C, Baskar D, Parker Y, et al. RNase $\mathrm{L}$ is a negative regulator of cell migration. Oncotarget 2015;6(42):44360-72. 